\title{
Is There Any Value in the Banks Brand?
}

\author{
Emanuel Bagna ${ }^{1}$ \\ ${ }^{1}$ Department of Economics and Management, Pavia University, Italy \\ Correspondence: Emanuel Bagna, Department of Economics and Management, Pavia University, Via San Felice, \\ 5 - 27100 Pavia, Italy. Tel: 39-382-986-244. E-mail: Emanuel.bagna@unipv.it
}

$\begin{array}{ll}\text { Received: October 20, } 2018 & \text { Accepted: November 17, 2018 } \quad \text { Online Published: November 26, } 2018 \\ \text { doi:10.5539/ijbm.v13n12p261 } & \text { URL: https://doi.org/10.5539/ijbm.v13n12p261 }\end{array}$

\begin{abstract}
Traditionally the literature show that public brand value estimates (such as the ones published by Interbrand, Brand Finance or Brand Z), in the context of industrial quoted companies, are incorporated in stock prices, implying that brands significantly contributes to the value generation process in a company. No such study was carried out at the level of the banking sector. This could be due to the attribution of a marginal importance of brands, among other intangible assets, in the banking sector, as highlighted by the literature. In more recent years more and more evidences give evidence of the importance of brands in banking sector; it should be noted that:

- many banks, as a result of the Purchase Price Allocation process - PPA (pursuant to IFRS 3 Business Combinations) consequent to banking aggregations (mergers or acquisitions), have booked in their financial statements (separate or consolidated) brand values;

- reports published by independent parties such as Brand Finance, publishes brand values specifically for the banking sector.

The aim of this article is therefore to assess if the brand contributes to the value generation process in the banking sector. To test our hypothesis we run a regression on a European sample between market capitalization of major banks and their brand value published by independent expert Brand Finance from 2008 to 2017, with a classic value relevance analysis. Our results demonstrate that brand contributes to the value generation process in the banking sector.
\end{abstract}

Keywords: brand valuation, value relevance, intangible assets, banking sector

JEL Classifications: M4; G14

\section{Introduction}

Historically, the literature on the subject of intangibles has unfolded along two main strands: a first one, in the context of management studies, which refers to the development and management of intangibles and a second one, related to accounting and finance studies, which refers to the measurement of intangibles and the effects on company value. This is based on the assumption that it is not possible to develop and manage (intangibles in this case) what one is not measurable (to evaluate the effects of the development and management). Measuring the value of intangible assets is closely related to their ability to contribute to the process of generating value within a company. The ability to measure the value translates into the knowledge of the drivers of the value itself and into the possibility to better manage the intangible asset and thus to control the process of generating value.

The aim of this article is to assess if the brand contributes to the value generation process in the banking sector. For this purpose, it should be noted that the management and marketing literature identifies different strategies and methods of managing a brand within the banking sector but without measuring the value that can be generated. Finance and accounting literature, in fact, has focused on measuring and evaluating for the banking sector only the contribution of customer relationships to intangibles, excluding from the analysis the brands. This does not mean that the literature denies the presence of brands, but simply that the brand in the banking sector does not contribute to generating value. This opinion is closely linked to a traditional view of the retail bank as rooted in the territory and based on two value drivers: on one hand the proximity and availability of "physical" branches in the region and therefore the potential proximity to the customer (bank branches close to clients' home) and, on the other hand, the ability to manage customer relations. The way of creating value of a traditional bank is therefore closely linked to 1) the achievement of the potential customer with the proximity of the 
branches and 2) the subsequent management of the customer relationships. The recent process of closing branches that involved all banks, along with the increasing use of the online channel, demonstrate how to reach potential clients is no longer necessary to have traditional channels represented by branches, but rather tools able to attract remote customers. In this respect, a strong brand is able to attract customers.

While there are numerous studies dealing with the measurement of the contribution of brands to the overall value of the company in the non-financial sector (from the pioneering work of M. Barth and others (1998) in terms of value relevance of the publication of brand values provided by independent third parties), there is no literature on measuring the contribution made by brands in the financial and, more in detail, in the banking sector. The aim of this work is therefore to fill this gap by trying to understand if the brand in the banking sector contributes to the process of generating value and therefore constitutes a valuable intangible asset.

In the banking industry there are no direct evidences of valuable brands represented mainly by market transactions with the exclusive purpose of brands. The evidence relating to the value of the trademarks is only indirect:

1) following the adoption of the international accounting standards in 2005 , the companies that carry out a merger or acquisition deal must, in fact, proceed with the allocation of the purchase price (Purchase Price Allocation - PPA) and the identification of the goodwill and specific intangibles, among which the brand assumes importance. In this regard, it should be noted that many banks, as a result of the Purchase Price Allocation process - PPA (pursuant to IFRS 3 Business Combinations) consequent to banking aggregations (mergers or acquisitions), have shown in their financial statements (separate or consolidated) positive value for brands; for this purpose, table 1 shows, for all the acquisitions and mergers in the European banking sector, starting from the adoption of the IAS, the valuations of the brands made at the PPA following the acquisition of other banks. The table shows how the number of brands recognized in the banks' balance sheets is not negligible. The lack of recognition of trademarks after 2012 is due to the lack of transactions involving banks;

Table 1. Banks that at the time of Purchase Price Allocation have recognized bank target brands within their financial statements

\begin{tabular}{llll}
\hline Year & Target Brand & Target country & Acquirer \\
\hline 2012 & Banco Pastor & Spain & Banco Popular Espanol \\
2010 & Deutsche Postbank & Germany & Deutsche Bank \\
2010 & First Republic Bank & US & Frist Republic Bank \\
2010 & Whitney National Bank & US & Hancock Holding \\
2009 & HBOS (Halifax Bank of Scotland) & UK & Lloyds Banking \\
2009 & Merrill Lynch & US & Bank of America \\
2009 & Fortis Bank & Belgium & BNP Paribas \\
2009 & Dresdner Bank & Germany & Commerzbank \\
2008 & St. George Bank & Australia & Westpac Banking \\
2008 & Banca Antonveneta & ltaly & Banca MPS \\
2007 & Sampo Pankki & Finland & Danske Bank \\
2007 & Capitalia & ltaly & Unicredit \\
2007 & Banca Lombarda e Piemontese & ltaly & Banche Popolari Unite \\
2007 & Sanpaolo lMl & ltaly & Gruppo lntesa \\
2006 & Denizbank & Turkey & Dexia \\
2006 & Finansbank & Turkey & National Bank of Greece \\
2006 & BNL & ltaly & BNP Paribas \\
2005 & ABSA (Amalgam. Bank of South Africa) & South Africa & Barclays \\
2005 & HVB Hypo und Vereinsbank & Germany & Unicredit \\
2005 & Banca Comerciala Romana & Romania & Erste Bank \\
2005 & Abbey National & UK & Santander \\
2005 & Aval & Ukraina & Raiffesen \\
\hline
\end{tabular}


2) companies specialized in brand valuation, among which Brand Finance, Inter brand and Brand $Z$, publish annual reports that are widely used and display significant brand values in the banking sector.

On the basis of this evidence, it can be concluded that among the practitioners it is widely believed that brands in the banking sector contribute to the process of generating value. The methodological approach used here, based on a classic analysis of value relevance, has made it possible to establish how the value of brands produced by independent third parties is incorporated in stock market prices and therefore how the financial market values the different banking brands in the valuations.

\section{The Contribution of Brand in the Value Generation of a Bank}

The main banks' intangible assets are represented by marketing intangibles. Among these ones, the dominant intangible is represented by the customer relationships that guarantee:

- on direct deposits (collection via deposits), the achievement of economic benefits (so-called markdown), given the possibility of reinvesting the deposits made by customers in assets and investments characterized by the same degree of risk and duration but with higher yield (for example the reinvestment of the deposits in government bonds of the same duration);

- in terms of indirect deposits (asset under management and asset under administration), the possibility of obtaining commissions from the assets management;

- on the lending front, the provision of economic benefits thanks to the possibility of offering loans at a rate higher than that which involves investments of equal risks and duration (so-called mark-up).

The benefits from the customer relationship management of direct deposits fell significantly as result of the expansive monetary policies that led to zero interest rates, while those related to the management of indirect deposits and loans rose at the same time.

Customer relations represent an intangible with fined useful life (since all customer relationships are destined to cease sooner or later), but which constitute - as a portfolio of relationships or a so called mass asset - an intangible asset with the ability to regenerate over time.

Alongside the customer relationship, there is the brand with a role that the international accounting standards define as that of a "contributory asset", ie facilitator of customer relationships. The brand has four main functions in the banking business:

1) it reduces the costs of acquiring new customers;

2) it reduces the risk perceived by customers (this role has increased significantly with the introduction of the bail-in legislation in Europe) and therefore it allows, all else being equal, a less onerous collection; this allows the bank to obtain a premium price on the products sold: higher markdowns in the case of sale of direct deposits (deposits), higher markups with the same risk in the case of sale of products linked to the supply of credit, higher management fees in the case of sale of products linked to indirect deposits;

3 ) it reduces the costs of customer relationships retention, extending their duration;

4) it facilitates cross-selling of banking products and services and therefore increases the bank's share of wallet towards multi-banking clients.

It should be noted that in the banking sector (like in other sectors) the existence of a recognized and visible brand is a necessary but not sufficient condition for the brand to generate value and therefore it constitutes a real intangible activity (ie a valuable intangible). One example is the case of the online banking operators, such as the ING Orange Account in its initial stages of development which introduced the new brand onto the market. Due to the aggressive marketing and advertising policy, it enjoyed good visibility, to which, however, it did not correspond a real economic benefit as demonstrated by the aggressive pricing policies in terms of the rate offered on new deposits that these operator had to offer to acquire and retain customers. Therefore a high degree of brand awareness in the banking sector, obtained with high advertising costs, does not necessarily imply the presence of an intangible asset (the brand) able to drive value creation.

Brands, in the banking industry, are typically attribute brands ${ }^{1}$ and therefore rely their image mainly on direct and indirect customer experience and brand awareness. This characteristic means that the quality of service, the trust gained over time and the professionalism in the performance of the service contribute to the generation of value. The growing importance of the role of the brand in the banking business is also highlighted by the creation of structures dedicated to the registration, management, maintenance and development of the brand.

The centrality of the brand in the banking sector is also reflected in the balance sheet and in the sustainability 
reports of banks; see, for example, the financial statements of Intesa Sanpaolo, the leading Italian listed bank, which highlights the strategic role of the brand:

"In the banking sector, where products and services are intangible, the image and reputation of a bank are of considerable importance in influencing consumer choices and perceptions. Intesa Sanpaolo, aware of the fact that the brand is a very important strategic asset, has always been keen on the measurement, enhancement and protection of the image and reputation of its brand." (Intesa Sanpaolo, 2015 Sustainability Report, page 55).

Indeed, alongside the company brands that insist on the distribution network (branches and/or promoters and/or private bankers), in the banking groups there are also many product and service brands which generally (but not necessarily) correspond to the brand of the same companies appointed to play the role of real "factories" of the group for specialized products / services. In large groups, therefore, there are simultaneously the presence of commercial brands used by the distribution networks and product/service brands used by the factories.

\section{Literature Review}

The literature review regarding the measurement of the brands value, refers to two main areas: a first one in the accounting and finance field relating to the value drivers in the banking sector, with particular reference to the intangible assets; and a second one relative to the value relevance of the valorization of the brands, produced by independent third parties which anyway makes use of samples of companies not belonging to the banking sector.

Few studies in the accounting and finance literature have analysed the role of intangible assets in the banking sector. The only ones to do so exhaustively are the studies of Calomiris and Nissim (2007) and of Begley and others (2006). The latter, based on the use of the residual income model to value companies, assess the value of a bank based on five drivers: bank equity, unrealized gains on non-performing loans, deposits (core deposits), loan portfolio in bonis and the activities that generate fees for the bank (mainly management of the indirect collection). The authors show how the difference between the value of a bank and its net assets derives mainly from core deposit activity and from activities that generate fees (ie intangible linked to customer relationships). From the analysis performed, it seems that the management of the loan portfolio is not able to generate value (in line with what found in the previous literature). The authors show how the method, even if it is able to significantly explain stock market prices, under-perform other criteria of financial nature and criteria that capitalize on bank income. In particular, the spread between stock market prices and shareholders' equity can be better explained on the basis of net income than on the intangibles modelled in the above proposed valuation method.

In a study of the National Bureau on Economics Research, Colomiris and Nissim (2007) developed an evaluation model of bank holding companies that takes into consideration a rather wide range of variables (32) obtaining an average $\mathrm{R}^{2}$ of $66 \%$; the authors point out that the largest part of the banks value derives from the management of deposits (core deposits) and loans. The multiples recorded in relation to the lending activity, ie the multiples expressed by the market on the book value of this item, are significantly lower than the multiples used in the valuation of the collection activity, to indicate that the collection activity generates greater extra-income. The authors then identify an important U-shaped relationship (U Shaped) between stock market prices and leverage, not analyzed by Begley et al. For example, extremely low leverage drives to high Price to Book Value multiples, meaning a positive valuation of the excess regulatory capital, to be interpreted according to Nissim, as an option to make investments with positive net present value. However, for significantly high levels of leverage, the authors observe an increase in the Price to Book Value, meaning that the market positively judges the benefit in terms of income deriving from higher levels of indebtedness higher than the benefit deriving from the additional risk of leverage. Finally, the author shows how the activity of maturity transformation (similar to a carry trade activity) does not generate value for banks per se. It should be noted that these two studies were carried out before the default of Lehman Brothers and are based on a traditional view of the banks, anchored to the management of customer relationships through "branches". The default of Lehman Brothers made clear on one hand the possibility of bankruptcy also for large banks, on the other hand the centrality of liquid bank deposits as a source of financing for loans. And in this respect the brand plays an essential role both in attracting new customers at low costs in deposits (guaranteeing the normal replacement of depositing assets) and in retaining its customers within the bank even in times of strong market turmoil(where there are phenomena of run into cash).

As regards the scientific literature concerning the value relevance of the brands, a first study by Barth and Clinch (1998) on the relevance of the different assets and the different evaluation criteria of the same, applied by the directors in the preparation of the financial statements and by independent experts during the evaluation, provide evidence that the intangibles of a sample of Australian companies, mainly represented by brands, are value-relevant. In a subsequent study, Barth et al. (1998), focusing on brands, show that the estimates of this 
class of intangibles represent important information for shareholders. In particular, the authors find a positive relationship between the ratings of 1,024 brands, published by Financial World from 1991 to 1996, and the market prices as well as the returns on shares. More specifically, the value of the brands is reflected in the value of the equity incrementally compared to the book values and the net income. Furthermore, the annual change in the value of this type of intangibles is positively correlated with the change in equity returns. Subsequently, Aaker and Jacobson (2001) evaluate the informative relevance of a specific component of brand equity, called brand attitude, which indicates the value of the brand perceived by consumers. Analyzing a sample of companies in the IT sector, the authors observe that changes in brand attitude affect the financial performance of the company. Kallapur \& Kwan (2004) test the effects of the capitalization of brands in a sample of 33 companies in the UK on market prices, starting in 1985. Unlike other authors, Kallapur \& Kwan base their study on the value of brand estimated by management at the time of the survey and, despite the tendency to overextend it, they observe a positive association with market prices and returns in the following 21 days from the announcement of the first capitalization of the brands. Mizik and Jacobson (2008), analyzing the "5 pillars" of the Young \& Rubicam model.

Bagna et al. (2017), analyzing a sample of industrial companies, instead show that among the different brand publications provided by independent third parties (Brand Finance, Brand $\mathrm{Z}$ and Interbrand) Brand Finance is characterized by the higher value relevance and reliability of published values, probably due to the evaluation criterion (royalty relief) adopted compared to other providers Intebrand adopts a criterion based on residual income while Brand $\mathrm{Z}$ a criterion based on stock market multiples).

\section{Research Hypothesis}

The main object of this article is to understand if the brand contributes to the value generating process in the banking sector. In order to explore if brand constitutes a valuable intangible asset in the banking sector we understand that:

a) independent expert such as Brand Finance provides a publication of the bank brand values;

b) Brand Finance is the independent expert for which brands' values in the industrial area, have proved to be more value relevant; this is probably due to the valuation method used in order to assess brand's value based on royalty relief;

c) the market capitalization of banks includes both value of tangible and intangible assets.

To check our hypothesis we proceeded with a classic value relevance analysis, verifying whether the public valuations of brands provided by brand Finance are incorporated in stock market prices and, therefore, contribute to the value generation process. The international literature (Barth et al., 1998, Bagna and others 2017) has already highlighted how the values published in the industrial field among others by Brand Finance are value relevant. However, such verification was not performed at banking sector level. For this reason it is possible to formulate the following hypothesis:

HP: Brand values published by Brand Finance are incorporated into the market capitalization of banks and therefore contribute to the process of generating value.

\section{Methodology}

\subsection{The Generating Value Process: The Underlying Algebra}

In order to evaluate the contribution made by the individual intangible assets to the whole value of a company (and a generic bank in this case), it is useful to refer to the residual income valuation model (or Ohlson-Juettner Model). This criterion enhances the equity value of a company on the basis of its net tangible assets (common equity) and on the basis of the ability to obtain net income higher than those that the net assets could generate if, rather than being employed in the company assets, they were invested in a well diversified portfolio of shares belonging to companies with the same risk (e.g. companies in the same sector with similar risk). The general evaluation formula is the follow:

$$
\begin{aligned}
\text { Equity Value }_{t=0}= & \mathrm{BV}_{t=0}+\sum_{t=1}^{T} \frac{\text { Net Income }_{t}-\mathrm{BV}_{\mathrm{t}-1} \mathrm{x} \text { coe }}{(1+\mathrm{coe})^{t}}+\text { Terminal Value } \\
& \text { Terminal Value }=\frac{1}{(1+\mathrm{coe})^{T}} \times \frac{\text { Net Income }_{T+1}-\mathrm{BV}_{T} \times \text { coe }}{\operatorname{coe}-\mathrm{g}}
\end{aligned}
$$

Where:

$\mathrm{T}=$ explicit forecast period 
$\mathrm{BV}_{\mathrm{t}-1}=$ common equity booked in the balance sheet at the beginning of the period $\mathrm{t}$;

$\mathrm{BV}_{\mathrm{t}}=$ common equity at the end of the year $\mathrm{t}$;

Net Incomet $-\mathrm{BV}_{\mathrm{t}-1} \mathrm{x}$ coe $=$ residual income

$\mathrm{Coe}=$ cost of equity (opportunity cost of capital)

Terminal Value $=$ Value of the company beyond the explicit forecast period

By placing:

Net Incomet $=\mathrm{BV}_{\mathrm{t}-1} \times$ Roe $_{\mathrm{t}}$

Where

$$
\text { Roe }=\text { Return on Equity }=\text { Net Incomet } / \text { Book Value }_{t-1}
$$

The following formula is obtained:

$$
\begin{gathered}
\text { Equity Value }{ }_{t=0}=\mathrm{BV}_{t=0}+\sum_{t=1}^{T} \frac{\left(\mathrm{Roe}_{t}-\mathrm{coe}\right) \mathrm{xBV}_{\mathrm{t}-1}}{(1+\mathrm{coe})^{t}}+\text { Terminal Value } \\
\text { Terminal Value }=\frac{1}{(1+\mathrm{coe})^{T}} \times \frac{\left(\mathrm{Roe}_{T+1}-\mathrm{coe}\right) \times \mathrm{BV}_{T}}{\mathrm{coe}-\mathrm{g}}
\end{gathered}
$$

That expresses the value of a company (a bank in that case) according to its residual income (roe - coe) and its tangible net assets.

The Residual Income formula expresses the financial value of a company based on:

1) the book value of its net assets, which expresses the historical cost of the investments made by the shareholders and

2) the capacity to generate income in excess of those achievable by competitors, as represented by the differential between the specific profitability of the company being valued (given by Roe) and the opportunity cost of capital that expresses a normal market remuneration obtained from the market participant.

The use of this valuation formula should therefore always induce the evaluator to look for the reasons underlying the achievement of residual income compared to competitors, highlighted by a profitability of equity above the capital cost opportunity. For a generic company, the answer to this question concerns the verification of the existence of some internally formed intangible asset, typically represented by:

- the existence of a brand that can guarantee the sale of a product at a price higher than that of products of the same quality (and costs of production) of the competition;

- the existence of historical customer relationships, which are also able to guarantee the sale of their products at a price higher than that of the competition;

- the development of technology that guarantees a better quality of service / product sold or alternatively a reduction in production costs compared to its peers;

- the presence of patents that could guarantee operations in a monopoly / oligopoly condition, which allows the application of premium price to products sold;

- the presence of key person among the top management, able to organize the business activity better than the competitors;

- and more generally the presence of goodwill connected to the ability to generate extra value over time.

The residual income formula is particularly useful in order to isolate the value of intangible assets, which in addition to being equal to the current value of residual profits, is equal, according to the formula, to the difference between the value of a company's equity and its net assets at time 0 :

$$
\begin{aligned}
& \text { Intangible Asset Value } \\
& t=0 \\
& =\text { Equity Value }_{t=0}-\mathrm{BV}_{t=0}= \\
& =\sum_{t=1}^{T} \frac{\left(\text { Roe }_{t}-\mathrm{coe}\right) \times \mathrm{xV}_{\mathrm{t}-1}}{(1+\mathrm{coe})^{t}}+\frac{1}{(1+\mathrm{coe})^{T}} \times \frac{\left(\mathrm{Roe}_{T+1}-\mathrm{coe}\right) \times \mathrm{xV}_{T}}{\mathrm{coe}-\mathrm{g}}
\end{aligned}
$$

Under the efficient market hypothesis, the equity value at time 0 corresponds to the stock market capitalization. By placing:

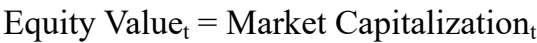


the value of intangible assets is therefore equal to the differential between the stock market capitalization and the net assets itself:

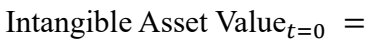

$$
\begin{aligned}
& =\text { Market Capitalization }{ }_{t=0}-\mathrm{BV}_{t=0}
\end{aligned}
$$

As will see below, in order to assess if an intangible asset $\mathrm{n}$ contributes to the value generation process, the following regression is performed:

$$
\text { Market Capitalization }=a+b_{\text {Book Value }} \times \text { Book Value }+b_{n} \times \text { Intangible Asset }_{n}
$$

If the parameter $b_{n}$ on the $n$-intangible is statistically significant, it can be established that this intangible asset contributes positively (and significantly from a statistical point of view) to the value process.

\subsection{Research Methodology}

To test our hypothesis we run a regression on a European sample between market capitalization of major banks and their brand value published by independent expert Brand Finance.

The possibility of using brand value estimates provided by independent third parties (such as Brand Finance) is directly linked to the value relevance of brand values expressed by Brand Finance. This means asking whether the brand values expressed by Brand Finance are incorporated into the stock exchange prices without incurring problems of endogeneity.

The value relevance analysis was carried out by referring to the value of brands published by Brand Finance for a sample of major European banks (the banks belonging to the Stoxx 600 index). The reports taken into consideration are the ones published by Brand Finance each year named "Banking 500 - The annual report on the world's most valuable banking brands". The value relevance hypothesis is tested using the approach provided by Mary Barth et al (1998), performed in 2 steps:

1) first of all analyzing the statistical significance of the relationship between the valuation of brands of different banks in the sample and their respective market capitalizations;

2) since the statistical significance founded at the first step could be due to an endogeneity factor (brand values are directly estimated from market prices, for example computing brand values as a fraction of the difference between the market value and common equity), a 2SLS model (Two-Stage Least Squares) has been used. That means verifying that the value estimated by Brand Finance are based on fundamental inputs and not on market parameters. The 2SLS simultaneous equations allow us to control the endogeneity factor and to verify that the statistical correlations do not arise from simultaneous bias. Therefore, by re-estimating brand values moving from fundamental parameters and excluding any reference to market variables (which therefore exclude stock market prices), we offer evidence about the correct interpretation of the relationship between market capitalizations and the brand values of the selected companies.

Verifying the value relevance of brands estimated by Brand Finance in the banking sector, is equivalent to examining the relationship between the market capitalizations of different banks of the sample and their brand values, performing the following regression:

$$
\begin{aligned}
\text { Mkt Cap }_{\mathrm{i}, \mathrm{t}}=\alpha+\beta_{\mathrm{Book}} \times & \text { Tangible Book Value }_{\mathrm{i}, \mathrm{t}}+\beta_{\text {Net Income }} \times \text { Net Income }_{\mathrm{i}, \mathrm{t}}+\beta_{\text {Brand }} \times \text { Brand Value }_{\mathrm{i}, \mathrm{t}}+ \\
& +\delta \text { CONTROL VARIABLES } i, t+\varepsilon
\end{aligned}
$$

where $i$ is the company owning brand $\mathrm{i}$; $\mathrm{t}$ is the year of analysis (2008 - 2017); Mkt Capi,t is the Market Capitalization of the i-company in t-period, observed at the end of each year; Tangible Book Value is common equity net of intangible asset, observed at the end of each year; as a common practice in the banking sector we use tangibile book value instead of book value, which is a proxy of regulated book value (common equity tier 1). Net Income is the net income for each fiscal year; Brand Value ${ }_{i, t}$ is the brand value estimated for the $i$-bank by brand Finance for the t-year. CONTROL VARIABLES include controls for: t-year of observation; h countries in which each company has its headquarter as specified in Table 2; negative return on equity; alla datas are taken from FactSet.

As our sample includes banks with high and low market capitalizations, dependent and independent variables are scaled by tangible equity in order to avoid the potential bias of the regression coefficients. The model proposed is thus equivalent to regress the price to tangible book value multiple (practioners use this market multiple to perform valuation in the banking sector) with respect to the return on tangible equity and the brand value of each company scaled by tangible book value: 


$$
\begin{gathered}
\frac{\text { Mkt Cap }_{i}}{\text { Tangible Book Value }_{i}}=\alpha+1+\beta_{\text {Net Income }} \times \frac{\text { Net Income }_{i}}{\text { Tangible Book Value }_{i}}+\beta_{\text {Brand }} \times \frac{\text { Brand Value }_{i}}{\text { Book Value }_{i}}+\delta \text { CONTROL_VARIABLESi,t }+\varepsilon \\
\frac{\text { Mkt Cap }_{i}}{\text { Tangible Book Value }_{i}}=\alpha+\beta_{\text {Roe }} \times \frac{\text { Net Income }_{i}}{\text { Tangible Book Value }_{i}}+\beta_{\text {Brand }_{1}} \times \frac{\text { Brand Value }_{i}}{\text { Tangible Book Value }_{i}}+\delta \text { CONTROL_VARIABLESi, } t+\varepsilon
\end{gathered}
$$

A positive and statistically significant coefficient $\beta_{\text {Brand }}$ proves the value relevance of the brands. In order to take into account the fact that the market expresses lower valuations for banks with negative income, we insert in the regression a variable equal to the product between i) a dummy variable that assumes unit value in case of negative income and otherwise null value and ii) the profitability of the bank. Furthermore, in order to take into account any differences in the valuation profile of different years and different countries, dummy variable countries and year were included.

\section{Results}

Table 2 shows descriptive statistics of the sample used. From the Brand Finance website we handly collect the value of major european banks (included in the Stoxx 600 Index) published in the report named "Banking 500 The annual report on the world's most valuable banking brands", after Lehman Brothers default (10 years, from 2008 to 2017).

Table 2. Descriptive statistics for the sample used in our analysis

\begin{tabular}{|c|c|c|c|c|c|c|}
\hline & $\begin{array}{l}\text { Market } \\
\text { Capitalization }\end{array}$ & Net Income & Pre Tax Income & Sales* & $\begin{array}{l}\text { Tangible } \\
\text { Book Value }\end{array}$ & $\begin{array}{l}\text { Brand } \\
\text { Value }\end{array}$ \\
\hline Mean & 18.087 & 911 & 1.785 & 10.162 & 16.854 & 3.385 \\
\hline Standard Deviation & 26.983 & 2.833 & 3.555 & 12.367 & 20.741 & 4.484 \\
\hline $1^{\text {st }}$ Quartile & 2.429 & 81 & 197 & 1.924 & 2.856 & 477 \\
\hline Median & 7.694 & 480 & 709 & 4.436 & 8.497 & 1.542 \\
\hline $3^{\text {rd }}$ Quartile & 24.950 & 1.717 & 2.873 & 16.015 & 23.883 & 4.724 \\
\hline Observations & 496 & 487 & 467 & 478 & 498 & 425 \\
\hline
\end{tabular}

a) Descriptive statistics

\begin{tabular}{|c|c|c|c|c|c|c|c|}
\hline & $\begin{array}{l}\text { Market } \\
\text { Tangible } \\
\text { Value }\end{array}$ & $\begin{array}{l}\text { Cap / } \\
\text { Book }\end{array}$ & $\begin{array}{l}\text { Return on Tangible } \\
\text { Equity** }\end{array}$ & $\begin{array}{l}\text { Brand } \\
\text { Tangible } \\
\text { Value }\end{array}$ & $\begin{array}{l}\text { Value / } \\
\text { Book }\end{array}$ & $\begin{array}{l}\text { Pre Tax Income } \\
\text { Margin*** }\end{array}$ & $\begin{array}{l}\text { Brand Value } \\
\text { / Sales }\end{array}$ \\
\hline Mean & 1,163 & & 0.042 & 0.256 & & 0,170 & 0.357 \\
\hline Standard Deviation & 0,756 & & 0,204 & 0,416 & & 0,554 & 0,457 \\
\hline $1^{\text {st }}$ Quartile & 0,679 & & 0,030 & 0,109 & & 0,100 & 0,215 \\
\hline Median & 1,021 & & 0,075 & 0,159 & & 0,201 & 0,278 \\
\hline $3^{\text {rd }}$ Quartile & 1,443 & & 0,117 & 0,230 & & 0,310 & 0,383 \\
\hline $1^{\text {st }}$ Percentile & 0,243 & & $-0,633$ & 0,050 & & $-1,082$ & 0,041 \\
\hline $99^{\text {th }}$ Percentile & 4,172 & & 0,358 & 2,364 & & 0,575 & 2,165 \\
\hline Observations & 481 & & 473 & 411 & & 467 & 407 \\
\hline
\end{tabular}

* Net Interest and other banking income

** Net Income / Tangible Book Value

*** Pre Tax Income / Net Interest and Other Banking Income

All data are expressed in euro mln 


\begin{tabular}{lc} 
b) Sample composition & by country \\
\cline { 2 - 2 } AUSTRIA & $3,1 \%$ \\
BELGIUM & $2,6 \%$ \\
CZECH REPUBLIC & $0,7 \%$ \\
DENMARK & $5,4 \%$ \\
FINLAND & $0,5 \%$ \\
FRANCE & $8,2 \%$ \\
GERMANY & $6,1 \%$ \\
GREECE & $3,8 \%$ \\
IRELAND & $2,1 \%$ \\
ITALY & $16,5 \%$ \\
NETHERLANDS & $1,4 \%$ \\
NORWAY & $2,4 \%$ \\
POLAND & $1,2 \%$ \\
PORTUGAL & $3,1 \%$ \\
SPAIN & $12,7 \%$ \\
SWEDEN & $8,7 \%$ \\
SWITZERLAND & $9,9 \%$ \\
UNITED KINGDOM & $11,8 \%$ \\
\hline
\end{tabular}

Source: FactSet, except for brand value (source:Brand Finance)

The most represented country in the sample is Italy with 16,5\% (table 2), followed by Spain (12,7\%) and Great Britain (11,8\%). Overall we collect 425 brand banking values over potential 496 data along 10 years. All data are converted in euro mln considering the relative exchange rate at year end. Average market capitalization is euro $18,087 \mathrm{mln}$, while average tangible book value amount euro 16,854 mln. Banks in the sample show a Return on Tangible Equity equal in median to 7,5\%, while the market multiple Price to Tangible Book Value equals 1,163: the high multiple indicates the presence of intangible assets estimated by the financial market for these banks. Brand values provided by Brand Finance are equal in median to $15,9 \%$ of the tangible equity.

Table 3 shows the results of the regression carried out relative to 400 brand values estimated by Brand Finance in the banking sector during the period 2008-2017 with reference to the main banks operating in Europe (for 25 banks there are alternatively no information for sales or tangible book value or net income).

Table 3. First Step - Value Relevance Analysis - regression results

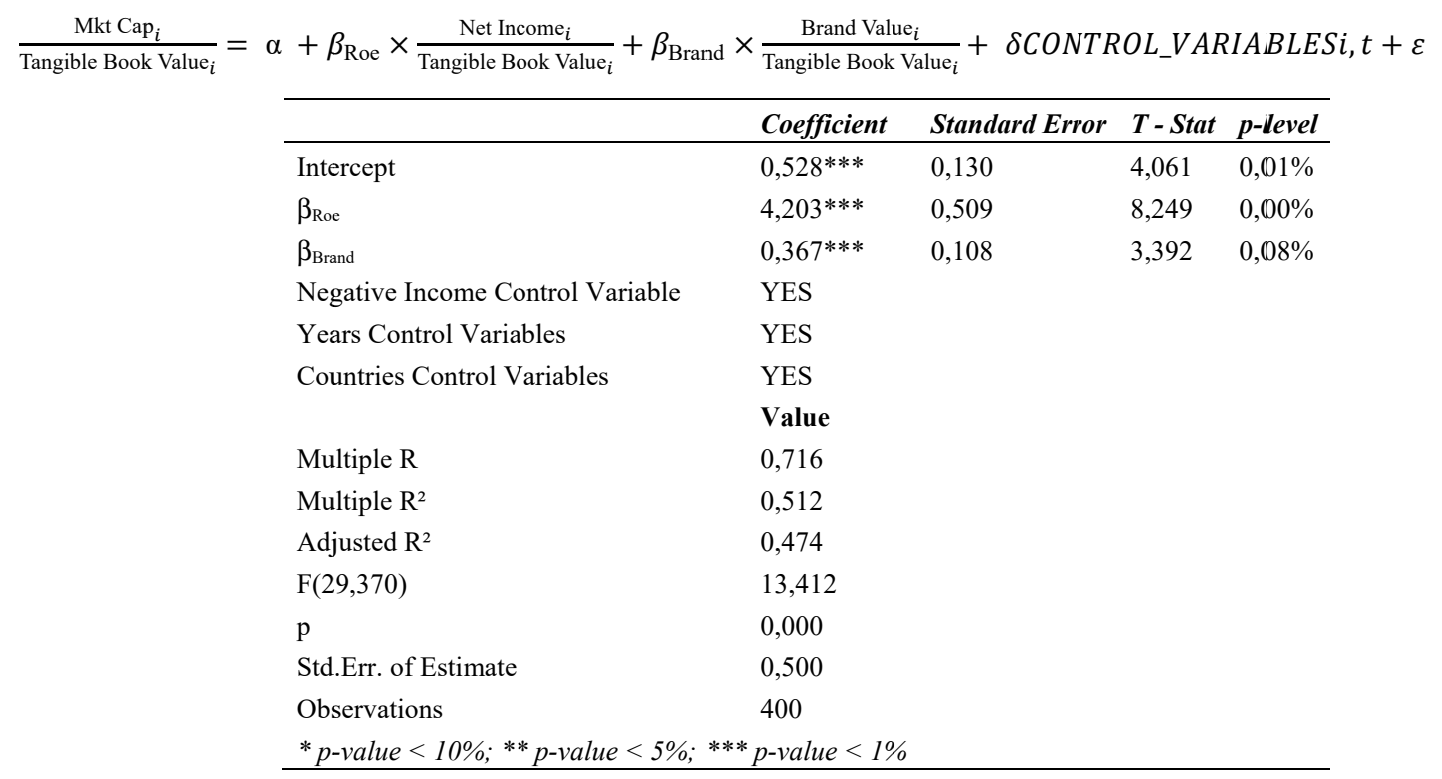


The table shows a positive and statistically significant coefficient bBrand, meaning that at this stage stock market prices incorporates the value of the brands supplied by Brand Finance. Because brand values published by Brand Finance could be inferred from market prices (causing endogeneity) we re-assess brand values using a model that does not depend on market prices (second step of Barth's verification). The model identified uses as a fundamental variable the gross (of tax) marginality (profit before tax / Net interest and other banking income ): higher margins should be accompanied by higher values of the brand (from a fundamental point of view the greater value of the brand derives from a higher royalty rate estimated for evaluation purposes). The regression used is therefore the following:

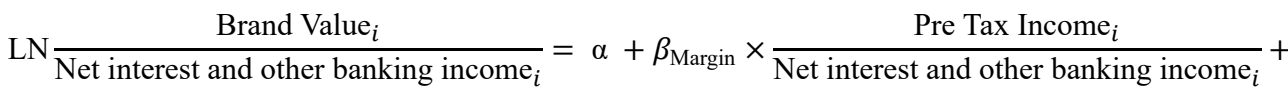

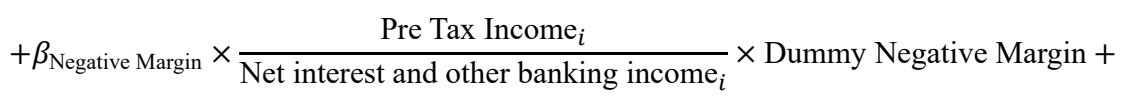

$$
\begin{aligned}
& +\delta C O N T R O L \_V A R I A B L E S i, t
\end{aligned}
$$

A should be noted, in order to avoid negative brand values, the natural logarithm (LN) of the [Brand value / (Net Interest and other banking income)] has been used. The regression considered, as in the previous case, a dummy variable able to capture the value of brands of banks with negative margins and dummy variables representing the risk of different countries and different years. The regression carried out (table 4) shows that the identified parameters have a good ability in order to explain the variance of the ratio (brand value / sales) of different banks, captured by an R2 (Adjusted) equal to 29,5\%. The regression also shows statistical significant coefficients ( $\mathrm{p}$-value $=0 \%$ ). Therefore we can infer that brand values estimated by Brand Finance are derived from fundamentals drivers, represented by the different bank margins.

Table 4. Second Step Value Relevance Analysis - First stage 2SLS results

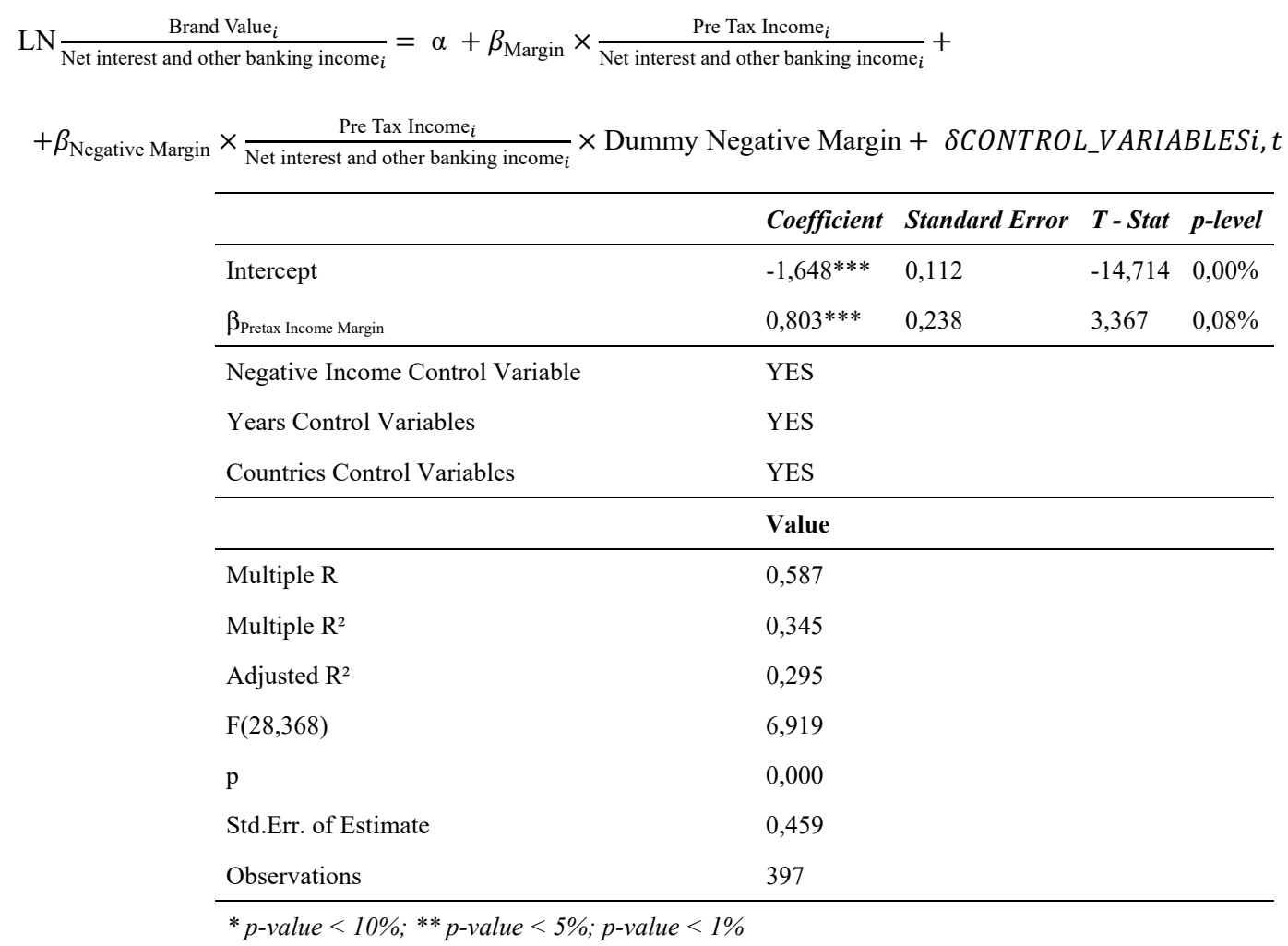

At this stage it is possible to understand the brand value relevance by verifying the relationship between the market capitalization of the different companies belonging to the Brand Finance sample and the re-estimated value of the brands, through the following regression: 


$$
\frac{\text { Mkt Cap }_{i}}{\text { Tangible Book Value }_{i}}=\alpha+\beta_{\text {Roe }} \times \frac{\text { Net Income }_{i}}{\text { Tangible Book Value }_{i}}+\beta_{\text {Brand }} \times \frac{\text { Re-estimated Brand Value }_{i}}{\text { Tangible Book Value }_{i}}+\delta \text { CONTROL_VARIABLESi, } t+\varepsilon
$$

which turns out to be identical to the regression used in the first step of the value relevance analysis (equation 6), but instead of using as independent variable the estimated Brand Value by Brand Finance, uses the brand value derived from fundamental drivers (pre tax income margin). This variable have been built using the value of the brands of each bank derived from regression coefficients in table 4.

As it can be seen from table 5 , the new $\beta_{\text {Brand }}$ coefficient significantly differs from zero and the adjusted $R^{2}$ is equal to $51 \%$. On the basis of this evidence it is possible to conclude that the brand values expressed by Brand Finance are value relevant and at the same time express valuations that move only from fundamental parameters.

Table 5. - Second Step Value Relevance Analysis - Second Stage 2SLS results

\begin{tabular}{|c|c|c|c|c|c|}
\hline \multirow[t]{16}{*}{$\frac{\text { Mkt Cap }_{i}}{\text { Tangible Book Value }}=$} & \multirow[t]{2}{*}{$\alpha+\beta_{\text {Roe }} \times \frac{\text { Net Income }_{i}}{\text { Tangible Book Value }}{ }_{i}$} & \multicolumn{4}{|c|}{$\times \frac{\text { Re-estimated Brand Value }_{i}}{\text { Tangible Book Value }_{i}}+\delta C O N T R O L_{-}$VARIABLESi, $t+\varepsilon$} \\
\hline & & Coefficient & Standard Error & $T$-Stat & p-level \\
\hline & Intercept & $0,448 * * *$ & 0,120 & 3,739 & $0,02 \%$ \\
\hline & $\beta_{\text {Roe }}$ & $3,867 * * *$ & 0,538 & 7,185 & $0,00 \%$ \\
\hline & $\beta_{\text {Brand }}$ & $0,651 * * *$ & 0,171 & 3,818 & $0,02 \%$ \\
\hline & Negative Income Control Variable & YES & & & \\
\hline & Years Control Variables & YES & & & \\
\hline & Countries Control Variables & YES & & & \\
\hline & & Value & & & \\
\hline & Multiple R & 0,716 & & & \\
\hline & Multiple $\mathrm{R}^{2}$ & 0,512 & & & \\
\hline & Adjusted $\mathrm{R}^{2}$ & 0,474 & & & \\
\hline & $\mathrm{F}(29,422)$ & 13,412 & & & \\
\hline & $\mathrm{p}$ & 0,000 & & & \\
\hline & Std.Err. of Estimate & 0,500 & & & \\
\hline & Observations & 452 & & & \\
\hline
\end{tabular}

\section{Conclusions}

Traditionally the literature show that public brand value estimates (such as the ones published by Interbrand, Brand Finance or Brand Z), in the context of industrial quoted companies, are incorporated in stock prices, implying that brands significantly contributes to the value generation process in a company. No such study was carried out at the level of the banking sector. This could be due to the attribution of a marginal importance of brands, among other intangible assets, in the banking sector, as highlighted by the literature and reflects a traditionalist view of the value generation process of a bank that binds value creation to:

a) the proximity of the bank to customers (the branches);

b) management of the customer relationship within the branch.

Following the default of Lehman Brothers, the way banks are managed has changed, also in light of the new technological paradigms, highlighting the role of the brand in the management of the bank. This role is evidenced by the fact that:

- many banks, as a result of the Purchase Price Allocation process - PPA (pursuant to IFRS 3 Business Combinations) consequent to banking aggregations (mergers or acquisitions), have booked in their financial statements (separate or consolidated) brand values;

- reports published by independent parties such as Brand Finance, publishes brand values specifically for the banking sector.

The article therefore set itself the objective of verifying whether the brand effectively contributes to the value creation process of a bank by performing a value relevance analysis. The analysis showed that the value of the banking brands published by the independent provider Brand Finance is incorporated in the stock exchange prices, reflecting the centrality of the brand in banking and the possibility of measuring it. 


\section{References}

Aaker, D. A., \& Jacobson, R. (2001). The Value Relevance of Brand Attitude in High-Technology Markets. Journal of Marketing Research, 38(4), 485-493. https://doi.org/10.1509/jmkr.38.4.485.18905

Ashbaugh, H., \& Olsson, P. (2002). An Exploratory Study of the Valuation Properties of Cross-Listed Firms' IAS and U.S. GAAP Earnings and Book Values. The Accounting Review, 77(1), 107-126. https://doi.org/10.2308/accr.2002.77.1.107

Bagna, E., \& La Valutazione delle Banche. (2012). EGEA.

Bagna, E., Bini, M., Bird, R., Momentè, F., \& Reggiani, F. (2010), Accounting for employee stock options: What can we learn from the market's perceptions? Journal of International Financial Management \& Accounting, 21(2), 161-186. https://onlinelibrary.wiley.com/doi/full/10.1111/j.1467-646X.2010.01039.x

Bagna, E., Di Martino, G. (2013). La value relevance della fair value hierarchy nel settore bancario europeo. Finanza Marketing E Produzione, 4.

Bagna, E., Di Martino, G., \& Rossi, D. (2015). No more discount under enhanced fair value hierarchy. Applied Economics, 47(51). https://doi.org/10.1080/00036846.2015.1054068

Bagna, E., Di Martino, G., Rossi, D. (2014). An Anatomy of The Level 3 Fair Value Hierar-chy Discount. No 65, DEM Working Papers Series from University of Pavia, Department of Economics and Management. p. 46. Retrieved from https://papers.ssrn.com/sol3/papers.cfm?abstract id=2367405

Bagna, E., Dicuonzo, G., Perrone, A., \& Dell'Atti, V. (2017). The value relevance of brand valuation. Applied Economics, 49(58). https://doi.org/10.1080/00036846.2017.1352078

Bagna, E., Ramusino, E. C., (2017). Market Multiples and the Valuation of Cyclical Companies. International Business Research, 10(12). https://doi.org/10.5539/ibr.v10n12p246

Barth, M. E., \& Clinch, G. (1998). Revalued Financial, Tangible, and Intangible Assets: Associations with Share Prices and Non-Market-Based Value Estimates. Journal of Accounting Research, 36, 199-233. https://doi.org/10.1111/j.1468-5957.2009.02133.x

Barth, M. E., Clement, M. B., Foster, G., \& Kasznik, R. (1998). Brand Values and Capital Market Valuation. Review of Accounting Studies, 3(1), 41-68. https://doi.org/10.1023/A:1009620132177

Begley, J., Chamberlain, S., \& Li, Y. (2006). Modeling Goodwill for Banks: A Residual Income Approach with Empirical Tests. Contemporary Accounting Research, 23(1). https://onlinelibrary.wiley.com/doi/abs/10.1506/DVWU-BWTW-B018-LMTA

Calomiris, C., \& Nissim, D., (2007). Activity-Based Valuation of Bank Holding Companies. NBER Working Paper No. W12918.

Courteau, L., Kao, J., \& Richardson, D. G. (2001). Equity valuation employing the ideal versus ad hoc terminal value expression. Contemporary Accounting Research, 18(4), 625-661. https://onlinelibrary.wiley.com/doi/abs/10.1506/77TK-1N3Q-82QU-UATR

Danielson, C., Grund, M., \& Gyllenhammar, J. (2007). Empirical testing of parsimonious equity valuation models. Stockholm School of Economics.

Dechow P., Hutton, A., \& Sloan, R. (1999). An empirical assessment of the residual income valuation model. Journal of Accounting and Economics. http://dx.doi.org/10.1016/S0165-4101(98)00049-4

Dechow, P., Hutton, A., \& Sloan, R. (1999). An empirical assessment of the residual income valuation model. Journal of Accounting and Economics, 26(1-3), 1-34. http://dx.doi.org/10.1016/S0165-4101(98)00049-4

Feltham, G., \& Ohlson, J. (1995). Valuation and clean surplus accounting for operating and financial activities. Contemporary Accounting Research, 11(2). https://doi.org/abs/10.1111/j.1911-3846.1995.tb00462.x

Feltham, G., \& Ohlson. (1999). Residual earnings valuation with risk and stochastic interest rates. Accounting Review, 74(2). https://doi.org/10.2308/accr.1999.74.2.165

Francis, J., Olsson, P., \& Oswald, R. (2000). Comparing the accuracy and explainability of dividend, free cash flow, and abnormal earnings equity value estimates. Journal of Accounting Research. https://doi.org/10.2307/2672922

Huang, J. (2015). A review of Brand Valuation Method. Journal of Service Science and Management, 8, 71-76. https://doi.org/10.4236/jssm.2015.81008 
Kallapur, S., \& Kwan, S. (2004). The Value Relevance and Reliability of Brand Assets Recognized by UK Firms. Purdue CIBER Working Papers, 18.

Kirk, C. P., Ray, I., \& Wilson, B. (2013). The impact of brand value on firm valuation: the moderating influence of firm type. Journal of Brand Management, 20(6), 488-500. https://doi.org/10.1057/bm.2012.55

Lundholm, R., \& O'Keefe, T. (2001). Reconciling value estimates from the dividend discount model and the residual income model. Contemporary Accounting Research, 18(2), 311-335.

Mizik, N., \& Jacobson, R. (2008). The Financial Value Impact of Perceptual Brand Attributes. Journal of Marketing Research, 45, 15-32. https://doi.org/10.1509/jmkr.45.1.15

Moore, B. J. (1988). A simple model of bank intermediation. Journal of Post Keymesian Economics, 12(1).

Nelson, K. K. (1996). Fair value accounting for commercial banks: An empirical analysis of SFAS No. 107. The Accounting Review, 71.

Nissim, D. (2003). Reliability of banks' fair value disclosure for loans. Review of Quanti-tative Finance and Accounting, 20. http://dx.doi.org/10.1023/A:1024072317201

Ohlson, J. (1995). Earnings, Book Values and Dividends in Security Valuation. Contemporary Accounting Research, 12(2), 661-687.

Ohlson, J. (2001). Earnings, book values and dividends in equity valuation: An empirical perspective. Contemporary Accounting Research, 18(1). https://doi.org/10.1506/7TPJ-RXQN-TQC7-FFAE

\section{Note}

Note 1. Trademarks are generally classified in three main groups:a) attribute brands. These brands transfer to the consumer a clear image of the quality of the good / service offered (for example "The McKinsey" is a typical brand that conveys a quality image in the field of strategic consulting); b) aspirational brands. These are brands that transfer to customers a clear image of the consumer profile in terms of status, recognizability, lifestyle (for example, Rolex is a brand that defines a status product for leading professionals); c) experience brands. These are brands that transfer to customers a clear image in terms of emotions associated with the product / service (so-called brand propositon.(Marlboro is a brand that transfers the image of genuine manhood, while Coca Cola transfers an image of belonging to the younger generations).

\section{Copyrights}

Copyright for this article is retained by the author(s), with first publication rights granted to the journal.

This is an open-access article distributed under the terms and conditions of the Creative Commons Attribution license (http://creativecommons.org/licenses/by/4.0/). 